\title{
An overview of information literacy studies in Turkey
}

\section{S. Serap Kurbanoglu*}

Associate Professor, Department of Information Management, Faculty of Letters, Hacettepe University, Beytepe 06532, Ankara, Turkey

Received 3 April 2003; accepted 9 July 2003

\begin{abstract}
Summary Although there exists a large body of literature related to information literacy; those reporting on research conducted in Turkey are few and far between. In this article, a chronological overview of these studies is presented. The total impact of information literacy studies conducted in Turkey has been less than satisfactory. The direct applications of information literacy have been limited mostly to private schools and universities with adequate funding, personnel, and technical infrastructure. The importance of the issue is far from ignored and several well meaning attemps are made to make information literacy a cornerstone of Turkish education. However, the realization of these efforts will require time and patience when the conditions of school and public libraries in the country are taken into account. It seems likely that university libraries are the best candidates to develop and maintain information literacy programs in the country.
\end{abstract}

(c) 2003 Elsevier Ltd. All rights reserved.

\section{Introduction}

The 20th century has often been considered as the age of information and technology. Societies are restructuring themselves in ways that react to technological, social and economic change. Recent decades have witnessed industrialized societies being transformed into information-based societies.

An information-based society needs individuals who have lifelong learning skills. Information literacy - the ability to find, use and communicate information - is the keystone of lifelong learning. The ability to read and write does not define

*Corresponding author. Tel.: +90-312-297-82-07; fax: +90312-299-20-14.

E-mail address: serap@hacettepe.edu.tr (S.S. Kurbanoglu). literacy in today's environment. Nowadays, the concept of literacy includes both computer literacy and information literacy. Information literate people are effective consumers of information. They are critical thinkers and self-directed learners, and they use and communicate information effectively and responsibly.

Every member of the information society should be equipped with information literacy skills to be able to succeed in school, at work and in daily life. In order to gain information literacy skills individuals should follow an information literacy program. Libraries of all sorts, play a central role in teaching information literacy skills and in integrating information literacy into the school curricula at all levels. Creating and maintaining information literacy programs that will support lifelong learning should become a mission for every library. Although 
there exists a large body of literature related to information literacy, and there is no sign that this trend will slow down in the near future, those reporting on research conducted in Turkey are few and far between.

Although traditional user education can be counted as a part of information literacy, there is no doubt that information literacy is a wider concept. In this article, studies and sources which were carried out and published only under the title or within the scope of information literacy are taken into account. To the best of my knowledge, what follows is the most complete chronological overview of studies on information literacy conducted in Turkey.

\section{The overview}

The concept of information literacy was first introduced to Turkish scholars in 1998 by Oya Gürdal in a speech (Gürdal, 1998) given at the meeting of the Association of Turkish Librarians and subsequently published in 2000 (Gürdal, 2000). Based mostly on material taken from foreign journals and books, Gürdal summarized various definitions of information literacy and its importance for lifelong learning and the obvious role which the librarians can play in providing information literacy instruction services. She further concluded that such efforts could bear fruit only if the students specializing in library science were introduced to new courses based on this most important topic.

A project for integrating information literacy into the curriculum of a private school (TED Ankara School) was put into effect in 1999. To the best of the author's knowledge, this was the first attempt at the development and delivery of an information literacy program for K-12 students. Headed by this author (educated in library science) and a colleague (an education specialist) the aim of this project was to equip students with information literacy skills which they could employ in their studies. As a first step, a pilot project was started during the spring term of the 1999-2000 school year, and the results were presented at the 66th IFLA General Conference (Kurbanoğlu \& Akkoyunlu, 2000). Using two groups composed of 6th graders (one of which served as a control group), the researchers found that the members of the group who were taught information literacy skills received significantly higher scores on their term papers compared with those in the control group. Furthermore, they also found that there was a statistically significant difference between the pre- and post-test results of the students who received information literacy instruction (Kurbanoğlu \& Akkoyunlu, 2002a).

In May 2000, a paper (Kurbanoğlu, 2000a) on how to give information literacy instruction was presented at Education in 21st Century Panel. During the same year, an information literacy workshop (Information Literacy Study Group, 2000) was organized for educators at the Education in the Light of IT Conference.

Following the above mentioned pilot project, a more comprehensive and wide-ranging project targeted to all 6th graders was initiated in the 2000-2001 school year at the same school. As a preliminary step, the scope and the aim of the project were presented to the teachers and school media specialists with special emphasis on the roles they were expected to play in the project. Topics addressed during the 15-week program included accessing information, locating and using information sources and the Internet, evaluating information sources, and writing a research paper. One of the most significant aspects of the project was the use of a micro-teaching technique to train those library personnel who had no previous expertise in the field of pedagogy. Pre- and post-tests, and evaluation of term papers indicated that the project was a success (Kurbanoğlu \& Akkoyunlu, 2001a).

The same year, information literacy workshops including hands on practices were organized for teachers from all levels and different branches at two Tevfik Fikret Schools, located in Ankara and İzmir. Difficulties and the problems encountered during the implementation of this project were discussed in an article (Akkoyunlu \& Kurbanoğlu, 2002). The necessity of equipping primary and secondary school teachers with information literacy skills, the impact of this training on active education and training information literate students, and the need for altering teacher education programs accordingly were among the topics addressed in this article.

In November 2000, a half-day seminar was given to the teachers of TED Ereğli School, in which the responsibility of schools and school media centers to equip students with information literacy skills was discussed (Kurbanoğlu, 2000b).

In May 2001, a paper (Yalvaç, 2001a) was presented at a seminar in i̇stanbul organized by The University and Research Librarians' Association and Marmara University. In this paper, requirements to become web literate in accordance with the fundamental standards of information literacy and the necessity for information professionals to perform activities like planning and managing of web 
site content and design, to be able to meet users' information requirements were explained. ACRL's (Association of College and Research Libraries) information literacy competency standards for higher education were introduced as prerequisites for information professionals to become information literates on the web (Yalvaç, 2001b).

In June 2001, a master's thesis (Kavuncu, 2001) was submitted to the Department of Information Management, Hacettepe University by the librarian of a private primary school associated with the Bilkent University. Although the author labels her efforts as "user education," in reality the project was an in-depth and detailed coverage of information literacy.

Keeping in mind that compulsory education in Turkey does not continue beyond 8th grade, this author proposed in an article (Kurbanoğlu, 2001a) that information literacy should be taught before students complete this grade. The obvious need for cooperation among teachers, educationalists and school media specialists was also strongly emphasized in the same article.

Two papers were presented on information literacy at "Information Concept While Entering 21st Century Symposium", in April 2001, in Hatay, Turkey. The first paper (Yalvaç, 2001c) which was later published, (Yalvaç, 2001d) examined ACRL's information literacy competency standards for higher education in detail and proposed that these standards should be used as guidelines for the education of information professionals. The second paper (Kurbanoğlu, 2001b) dealt with the concept of information literacy and on-going projects which were already described in the previous publication.

During the 2001-2002 school year, the on-going TED School project referred to above continued with the inclusion of 7 th grade students so that any problems arising during the previous program could be remedied. Practical applications of the course material were also encouraged. During the same year, homework preparation guides for beginners, intermediate and advanced (Kurbanoğlu \& Akkoyunlu, 2001b, 2001c, 2001d) students were also prepared because of the perceived need.

A report by the Special Ad Hoc Committee on Information Technologies and Policies published by the State Planning Organization provides a basis for the Turkish Government's long-term strategy and 5-year development plan, and points out the inadequacy of the information literacy level in the country. It also emphasizes the need to provide information literacy education in all sorts of education organizations in all levels and the need to develop school and public libraries to support information literacy and lifelong learning (Informa- tion Technologies and Policies Special Ad Hoc Committee Report, 2001). Although the government's involvement in this important subject was gratifying, the ensuing "The Long-Term Strategy and Eight Five-Year Development Plan for 20012005" (Devlet Planlama Teşkilatı, 2000) included the importance of lifelong learning and problemsolving skills but ignored information literacy.

One of the other activities in these studies was a half-day seminar (Kurbanoğlu, 2002) given to librarians at the New Developments in Librarianship Seminar, March 2002, in Ankara as a part of 38th Library Week activities.

During the 2001-2002 school year, an information literacy program was undertaken at Hacettepe University targeted to seniors majoring in initial teacher training. The effectiveness of this information literacy program was discussed in an article (Kurbanoğlu \& Akkoyunlu, 2002b). Students' perceived computer self-efficacy, and the relationship between their perceived computer self-efficacy and information literacy achievement were also examined. An achievement test (pre and post), a computer self-efficacy scale and an information literacy proficiency scale were used for evaluation. Results have shown that the program was satisfactory as a whole; however, perceived computer selfefficacy of initial teacher training students was inadequate and there was a positive correlation between their perceived computer self-efficacy and their achievement in the information literacy course. It was also found that initial teacher training students needed more detailed instruction on both computer and information literacy.

A paper (Saatçıoğlu, Özmen \& Özer, 2002) was presented at the First National Congress on Information, Economics and Management, in May 2002. Advantages and disadvantages of different applications to teach information literacy skills, like course-integrated instruction, drop-in workshops, online web base instruction, stand-alone courses and subject specific instruction were among the highlights in this speech. Following this presentation, researchers began a campus-wide information literacy instruction program for the Dokuz Eylül University, Izmir, Turkey. The main aim of this project was to equip not only undergraduate students, but also graduate students, with information literacy skills. Several explanatory seminars were given prior to the onset of the program. The expected beneficiaries of this project were estimated to be several thousand undergraduate and graduate students (Saatcioğlu, 2002). One questionable aspect of this project was that at this writing no professional librarians have been invited to participate. 
In August 2002, a poster session (Yalvaç, 2002) was presented at the 68th IFLA General Conference. The main aim of this presentation was to emphasize the importance of lifelong learning, which obviously includes IL, and the role of libraries to facilitate the prospective membership of Turkey in the European Union.

Turkey joined PULMAN-XT Project (Public Libraries Mobilizing Advanced Networks) in April 2002. Within the framework of this project a national meeting was held in Ankara, Turkey, in the following November. In this meeting PULMAN principles and their applicability to Turkish public libraries, lifelong learning and the role of public libraries in supporting lifelong learning were discussed. How public libraries should support lifelong learning and information literacy and the necessity of planning in-service training on information literacy for Turkish public librarians and the importance of the cooperation of public libraries with all other regional, national, international cultural and educational organizations were enumerated in the final report (Yllmaz, 2003). However, with few exceptions many Turkish public libraries are not fully equipped to participate in such a project.

In October 2002 a new elective course titled "Information Retrieval and Research Techniques" by the Ministry of Education (Milli Eğitim Bakanlığı, 2002) was prepared for high school students. Information literacy is a major component of this course, which will include subjects such as how to use libraries, learning about information sources, how to prepare homework and how to avoid plagiarism. It must be noted that most schools lack the adequate infrastructure to undertake this project.

\section{On-going research projects and studies}

Two ongoing research projects at Hacettepe University carried out by post-graduate students also deal with information literacy. One (Polat, in preparation) aims to ascertain the degree of competency of graduate students in information literacy and to develop a model for information literacy instruction at the university level, and the other (Aldemir, in preparation) focuses on information literacy for initial teacher training students at Sakarya University.

Two more studies are being carried out by Akkoyunlu and Kurbanoğlu at the same university. One is in the process of evaluating students' perceived self-efficacy on information literacy and how this perception develops over the years, as well as its relationship with the computer selfefficacy. The second project is about the information literacy self-efficacy perceptions of university librarians who take part in user education.

\section{Conclusion}

Although there have been some studies related directly and indirectly to information literacy in Turkey, their total impact has been less than satisfactory. This is not surprising when we consider the fact that the term itself gained currency only in 1998. Furthermore, the direct applications of information literacy have been few and far between, limited mostly to private schools and universities with adequate funding and personnel and technical infrastructure, such as access to the Internet and relevant literature. The importance of this issue has not been ignored and several wellmeaning attempts have been made during the last few years to make information literacy a cornerstone of Turkish education. However, when the conditions of school and public libraries in the country are taken into account, it seems likely that the realization of these efforts will require time and patience.

Under the present circumstances, the best candidates for developing and using information literacy programs in the country are the university libraries. Although, almost all the university libraries in the country have user education programs, some of which compare favorably with their counterparts in Western countries, it is recommended that these libraries should review their programs in light of ACRL's information literacy standards for higher education. Modification of these standards fitted to local needs should also be considered.

A national plan on this very important subject should be prepared and implemented. In order to undertake such an effort, librarians should cooperate not only with their colleagues but also with members of the faculty both in library science and education departments. Considering the degree of expertise, experience and access to the resources, such an effort should be spearheaded by the university librarians.

\section{References}

Akkoyunlu, B., \& Kurbanoğlu, S. (2002). Öğretmenlere bilgi okuryazarlığı becerilerinin kazandırılması üzerine bir çalışma [A study on teaching information literacy skills to teachers]. Türk Kütüphaneciliği, 16, 123-138. 
Aldemir, A. (in preparation). Öğretmen adaylarının bilgi okuryazarlığı düzeyleri: Sakarya Üniversitesi örneği [initial teacher training students' information literacy levels: Sakarya University example]. Master's Thesis, Hacettepe University, Ankara, Turkey.

Devlet Planlama Teșkilatı. (2000). Uzun vadeli strateji ve sekizinci beş yıllık kalkınma planı: 2001-2005 [Long-term strategy and eight five-year development plan: 2001-2005]. (pp. 82, 84, 126, 222-223). Ankara: Devlet Planlama Teşkilatı.

Gürdal, O. (1998) Yaşam boyu öğrenme etkinliği: Enformasyon Okuryazarlığı [Activity of lifelong learning: 'Information literacy'.] Paper presented at III. Kütüphane Konferansı [The 3rd Library Conference], Ankara, Turkey.

Gürdal, O. (2000). Yaşam boyu öğrenme etkinliği: Enformasyon Okuryazarlığı [Activity of lifelong learning: information literacy]. Türk Kütüphaneciliği, 14, 176-187.

Bilgi Okuryazarlığı Çalışma Grubu [Information Literacy Study Group]. (2000). Bilișim Teknolojileri Ișığında Eğitim Konferanst. [Education in the light of the IT conference], 13 May 2000, Ankara.

Bilişim Teknolojileri ve Politikaları Özel ihtisas Komisyonu raporu [Information Technologies and Policies Special Ad Hoc Committee Report]. (2001). Sekizinci Beș Yıllık Kalkınma Planı Yayın No. DPT: 2560-ÖiK 576. Ankara: Devlet Planlama Teșkilatı (pp. 28, 43, 45).

Kavuncu, E. (2001). Özel ilköğretim okul kütüphanelerinde kullanıcı eğitim programlarının geliștirilmesi [Developing user education programs in private primary schools]. Unpublished Master's Thesis, Hacettepe University, Ankara, Turkey.

Kurbanoğlu, S., (2000a). Bilgi okuryazarlığı eğitimi [Information literacy education]. Paper presented at 21 Yüzyılda Eğitim Paneli [Education in 21st century panel], Ankara, Turkey.

Kurbanoğlu, S. (2000b). Bilgi okuryazarlığı eğitiminde okulların ve kütüphanelerin sorumlulukları [The responsibility of schools and school media centres on information literacy instruction]. Paper presented at Bilgi Okuryazarlığı Semineri [Information literacy seminar], Ereğli, Turkey.

Kurbanoğlu, S. (2001a). Öğrencilere bilgi okuryazarlığı becerilerinin kazandırılmasının önemi ve okul kütüphanecilerinin bu alandaki rolü [The importance of teaching information literacy skills to students and the role of school media specialists on this issue]. Bilgi Dünyası, 2, 1-19.

Kurbanoğlu, S. (2001b). Bilgi okuryazarlığı [Information literacy]. Paper presented at 21 Yüzyıla Girerken Enformasyon Olgusu Sempozyumu [Information concept while entering 21st century symposium], Hatay, Turkey.

Kurbanoğlu, S. (2002). Bilgi okuryazarlığı [Information literacy]. Paper presented at Kütüphanecilikte Yeni Gelișmeler Semineri. [New developments in librarianship seminar], Ankara, Turkey.

Kurbanoğlu, S., \& Akkoyunlu, B. (2000). Lifelong learning in an increasingly globalised world of information: an information literacy project for K-12 community. Poster session presented at the 66th IFLA General Conference and Council, Jerusalem, Israel.

Kurbanoğlu, S., \& Akkoyunlu, B. (2001a). Öğrencilere bilgi okuryazarlığı becerilerinin kazandırılması üzerine bir çalıșma [A study on equipping students with information literacy skills]. Hacettepe Üniversitesi Eğitim Fakültesi Dergisi, 21, 81-88.

Kurbanoğlu, S., \& Akkoyunlu, B. (2001b). Ödev hazırlama kılavuzu: Başlangıç düzeyi [Homework preparation guide: Beginners]. Ankara: TED Ankara Koleji.

Kurbanoğlu, S., \& Akkoyunlu, B. (2001c). Ödev hazırlama kılavuzu: Orta düzey [Homework preparation guide: Intermediate]. Ankara: TED Ankara Koleji.
Kurbanoğlu, S., \& Akkoyunlu, B. (2001d). Ödev hazırlama kılavuzu: Illeri düzey [Homework preparation guide: Advanced]. Ankara: TED Ankara Koleji.

Kurbanoğlu, S., \& Akkoyunlu, B. (2002a). Bilgi okuryazarlığı: Bir ilköğretim okulunda yürütülen uygulama çalışması [Information literacy: A study applied in a primary school]. Türk Kütüphaneciliği, 16, $20-40$.

Kurbanoğlu, S., \& Akkoyunlu, B. (2002b). Öğretmen adaylarına uygulanan bilgi okuryazarlığı programının etkililiği ve bilgi okuryazarlığı becerileri ile bilgisayar öz-yeterlik algısı arasındaki ilişki [Effectiveness of information literacy program applied to initial teacher training students and relation between students' information literacy skills and perceived computer self efficacy]. Hacettepe Üniversitesi Eğitim Fakültesi Dergisi, 22, 98-105.

Milli Eğitim Bakanlığı (2002). Bilgi erişim ve araştırma teknikleri dersi öğretim programı [Instruction program of the information retrieval and research techniques course]. Milli Eğitim Bakanlığı Tebliğler Dergisi, 65, 890-903.

Polat, C. (in preparation). Üniversitelerde kütüphane merkezli bilgi okuryazarlığı programlarının olușturulması: Hacettepe Üniversitesi örneği [Developing library centered information literacy programs at universities: Hacettepe University example]. Ph.D. Thesis, Hacettepe University, Ankara, Turkey.

Saatcioğlu, Ö. (2002). Personal communication, December 23, 2002.

Saatçıŏlu, Ö., Özmen, Ö., \& Özer, P.S. (2002). Bilgi okuryazarlığı: Üniversite eğitiminde yeni bir boyut [Information literacy: A new dimention in the university education]. In Yumuşak, i.G., \& Dönmez, M.A. (Eds.) I. Ulusal Bilgi, Ekonomi ve Yönetim Kongresi Bildiriler Kitabı[First National Congress on Information, Economics and Management proceedings]. (pp. 287-299). Kocaeli: Kocaeli Üniversitesi.

Yalvaç. M. (2001a). Web'de enformasyon okuryazarlığı [The information literacy on the web]. Paper presented at Kütüphanelerde Web Sitesi Planlaması ve Yönetimi Semineri [Planning and management of web sites in libraries seminar], İstanbul, Turkey.

Yalvaç, M. (2001b). Web'de enformasyon okuryazarlığı [The information literacy on the web]. Bilgi Dünyası, 2, 48-66.

Yalvaç, M. (2001c). 21 Yüzyılda enformasyon profesyonellerinin eğitim ve öğretiminde enformasyon okuryazarlığı standartları [Information literacy standards for the information professionals' education in 21st century]. Paper presented at 21, Yüzyıla Girerken Enformasyon Olgusu Sempozyumu [Information concept while entering 21st century symposium], Hatay, Turkey.

Yalvaç, M. (2001d). 21 Yüzyılda enformasyon profesyonellerinin eğitim ve öğretiminde enformasyon okuryazarlığı standartları [Information literacy standards for the information professionals' education in the 21st century]. Türk Kütüphaneciliği, $15,136-150$.

Yalvac, M. (2002). The concept of lifelong learning in the framework of the integration of Turkey with the European Union: How libraries can support it. Paper presented at the 68th IFLA General Conference and Council, Glasgow, Scotland.

Yılmaz, B. (Ed.). (2003). Bilgi toplumuna dogru halk kütüphaneleri: Pulman XT Türkiye ulusal toplantısı sonuç raporu, 16-19 Kasım 2002, Milli Kütüphane, Ankara [Public libraries towards information society: Final report of Pulman XT National Meeting of Turkey, 16-19 November 2002, National Library, Ankara]. Ankara: Türk Kütüphaneciler Derneği. 